\title{
A NUMERICAL SIMULATION OF THE WIND-DRIVEN WATER CIRCULATION ON THE SUNDA SHELF ${ }^{1}$
}

\author{
by \\ Gordon W. Groves ${ }^{2,3}$ \\ and \\ GARY NIEMEYER $^{2}$ \\ (Manuscript received 4 July 1973)
}

\begin{abstract}
A numerical simulation of the barotropic circulation over the Sunda Shelt was carried out for a time-invariant wind field corresponding to (a) the Northwest Monsoon and (b) the Southeast Monsoon seasons. Starting from a state of rest, the current and surface configurations were timestepped until an apparent state of equilibrium was reached. The resulting current pattern and sea-surface topography are in good agreement with observations during those two seasons.
\end{abstract}

\section{IKHTISAR}

Suatu peniruan angkawi untuk menaksir arus dan topografi permukaan laut yang diakibatkan tiupan angin di daerah Dangkalan Sunda sudah dilakukan. Harga harga komponen arus horizontal dan tinggi rendahnya permukaan laut pada jaringan titik-titik berjarak satu sama lain seperempat derajat yang meliputi seluriih daerah Dangkalan Sunda telah ditaksir. Penghitungan tersebut dilaksanakan atas dasar pola angin yang konstan untuk segala waktu. Sebagai permulaan digunakan keadaan arus nol dan permukaan laut sama sekali rata. Pada saat permulaan itu angin dibiarkan bekerja mempengaruhi permukaan laut. Dalam keadaan demikian besarnya komponen arus, dll., pada setiap titik jaringan dihitung dari waktu ke waktu, sehingga pola arus dan topografi permukaan laut menjadi tetap tak berubah-ubah lagi.

Persamaan gerak yang dipakai ialah dari LAPLACE dengan tambahan satu suku lagi guna memperhitungkan geseran arus pada dasar laut. Geseran tersebut dianggap kwadratik dalam penelitian ini dan sukunya dalam persamaan gerak merupakan satu-satunya yang tidak linear. Arus-arus dianggap mendatar dan konstan sepanjang setiap garis tegak. Keadaan demikian terkenal sebagai teori gelombang panjang, dan berbagai pengalaman telah menunjukkan bahwa pada kasus-kasus dimana syarat tersebut tidak terpenuhi, arus yang dihitung biasanya masih mewakili pemindahan massa, yaitu besarnya kecepatan arus rata-rata sepanjang garis tegak, dengan cukup ketelitian.

Pola angin yang diselidiki ialah dua. Yang pertama lala'h peniruan pola angin musim barat sedangkan yang kedua ialah peniruan pola angin musim timur. Arusarus yang dihasilkan oleh peniruan angkawi ini telah dibandingkan dengan hasil-hasil pengamatan langsung. Pada umumnya pola arus serta topografi permukaan laut menurut kedua hasil tersebut hampir sama, meskipun kecepatan arus berdasarkan peniruan angkawi agak kurang dari yang diamati secara iangsung. Hal ini mungkin disebabkan oleh pilihan harga koefisien geseran yang agak tinggi.

1 Contribution number 548, Hawaii Institute of Geophysics

${ }^{2}$ Hawaii Institute of Geophysics, University of Hawaii, Honolulu, Hawaii 96822.

3 Now at -

Pusat Pengajian Sains Fizik, Universiti Sains Malaysia, Pulau Pinang. 


\section{INTRODUCTION}

The Sunda Shelf is unique among marine environments in the ocean. It comprises the entire Java Sea eastward to the Makasar Strait, the Karimata Strait, the Gulf of Thailand, and the southwestern part of the South China Sea. The mean depth of this two million square kilometer area is only about seventy meters, while the maximum depth contained therein is a mere hundred meters or so. The shelf is bounded either by coastlines or by steep slopes leading to deep oceanic areas. The problem of nutrient replenishment is unique because decaying dead organisms do not sink into deep waters, and there is no deep upwelling. The currents in the region are everywhere directly influenced by bottom friction. As a consequence, the water is usually mixed by turbulent diffusion in each vertical column, and thermal features such as thermoclines are often absent from bathythermographs.

The present study is a numerical simulation of the current field assuming that the horizontal motion is everywhere independent of vertical coordinate. Deviations of the sea surface from its mean level are considered small compared to the water depth at each point, and the current speeds are considered vanishingly small. That is, linear theory is used throughout except for representation of the bottom friction. The other usual assumptions characteristic of the barotropic long-wave approximation are made. The equations:

$$
\begin{aligned}
& \frac{\partial U}{\partial t}-f V=-g \frac{\partial s}{\partial x}-r H^{-1} U \sqrt{U^{2}+V^{2}}+p^{-1} H^{-1} T_{x} \\
& \frac{\partial V}{\partial t}+f U=-g \frac{\partial s}{\partial y}-r H^{-1} V \sqrt{U^{2}+V^{2}}+p^{-1} H^{-1} T_{y} \\
& \frac{\partial s}{\partial t}+\frac{\partial}{\partial x}(H U)+\frac{\partial}{\partial y}(H V)=0
\end{aligned}
$$

are taken to be those governing the water motion. Here, $\mathrm{t}$ is time, the cartesian coordinates $(\mathrm{x}, \mathrm{y})$ are in the eastward and northward directions, respectively. $\mathrm{U}(\mathrm{x}, \mathrm{y}, \mathrm{t})$ and $\mathrm{V}(\mathrm{x}, \mathrm{y}, \mathrm{t})$ are the horizontal velocity components in those directions, $6(\mathrm{x}, \mathrm{y}, \mathrm{t})$ is the deviation of the sea-surface elevation above its mean position, $\mathrm{f}(\mathrm{y})$ is the coriolis parameter, $p$ is sea-water density, $r$ is a nondimensional bottomfriction coefficient, $\mathrm{g}$ is acceleration of gravity, $\mathrm{H}(\mathrm{x}, \mathrm{y})$ is water depth, and $T_{X}(\mathrm{x}, \mathrm{y}, \mathrm{t})$ and $T_{Y}(\mathrm{x}, \mathrm{y}, \mathrm{t})$ are components of the surface wind stress. The equations as they stand make no provision for treating the effects of the normal atmospheric pressure variations or tidal forces. The only driving force considered is the surface wind stress. The bottom friction is assumed to obey a quadratic law with coefficient $r$. 


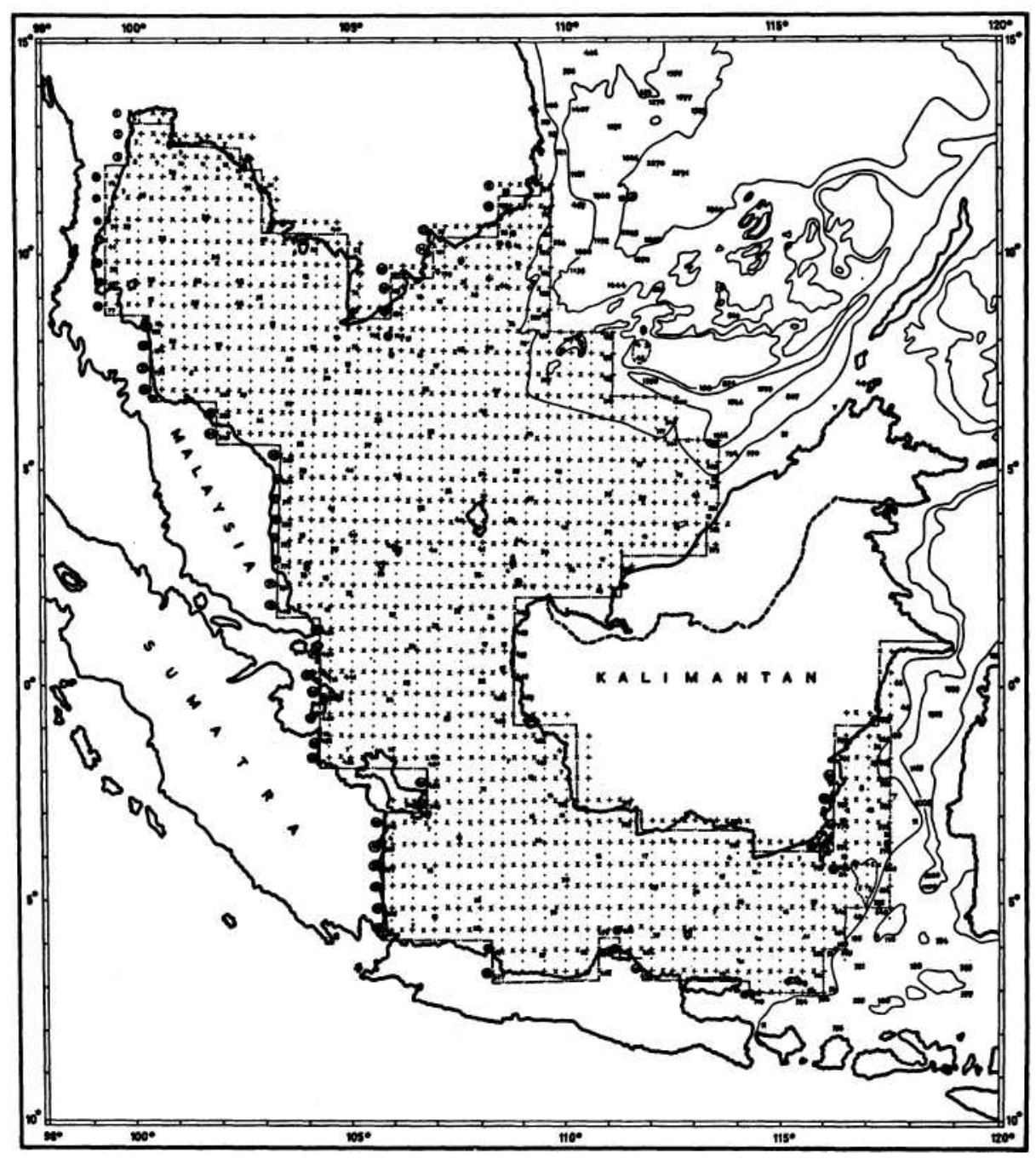

Figure 1.

Computational grid with $\mathrm{x}=\mathrm{u}$-points;.$=\mathrm{v}$-points; and $+=\zeta$-points. 


\section{DisCRETIZATION}

Only first derivatives occur in (1). The spatial derivatives will be replaced by central difference formulas and the time derivatives by forward differences. To simplify the notation, let the dependent variables at displaced points be indicated as follows:

$$
\begin{array}{ll}
Z & \text { stands for } s(x, y, t) \\
Z_{t+1} & \text { stands for } s(x, y, t+\Delta t) \\
U_{x-2} & \text { stands for } U(x-2 \Delta x, y, t), \text { etc. }
\end{array}
$$

where $\Delta \mathrm{x}, \Delta \mathrm{y}$, and $\Delta \mathrm{t}$ are appropriately-chosen intervals in $\mathrm{x}, \mathrm{y}$ and $\mathrm{t}$. The derivatives in (1) are then approximated by the expressions

$$
\begin{aligned}
& \frac{\partial U}{\partial t}=\frac{U_{t+2}-U}{2 \Delta t} \\
& \frac{\partial s}{\partial x}=\frac{Z_{x+1}-Z_{x-1}}{2 \Delta x}, " \text { etc. }
\end{aligned}
$$

PlATZMAN (1963) gives a thorough discussion of the possible square grids that can be used with this and related problems. The one used here is that of HANSEN, which has been used in many numerical tide simulations over the years (BRETTSCHNEIDER 1967, and HANSEN 1962). Figure 1 shows the geometrical layout. It is noted that the meridional coastal boundaries must pass through U-points, at which the U-values are taken as zero, and similarly the latitudinal coastal boundaries must pass through Vpoints, at which the $\mathrm{V}$-values are taken as zero. A condition on $\mathrm{Z}$ must be applied at the non-coastal boundary points. These are located in deep water near the steep bottom slopes which form the transition region between the Sunda Shelf and the deeper seas. In a barotropic model the surface tangential wind stress would produce very small surface elevations in water sufficiently deep. Consequently, the $Z$ values at the non-coastal boundary points are taken to be zero.

A timestepping procedure is used wherein $Z$ is computed at even intervals of $\Delta \mathrm{t}, \mathrm{U}$, and $\mathrm{V}$ at odd intervals. The appropriate equations for use on this grid then become 


$$
\begin{aligned}
& U_{t+1}=U_{t-1}+2 \Delta t\left[-\imath H^{-1} U_{t-1} \sqrt{U_{t-1}^{2}+\widetilde{V}_{t-1}^{2}}+f \tilde{V}_{t-1}-\frac{g}{2 \Delta x}\left(Z_{x+1}-Z_{x-1}\right)+\rho^{-1} H^{-1} T_{x}\right] \\
& V_{t+1}=V_{t-1}+2 \Delta t\left[-\lambda H^{-1} V_{t-1} \sqrt{\tilde{U}_{t-1}^{2}+V_{t-1}^{2}}-f U_{t-1}-\frac{2}{2 \Delta y}\left(Z_{y+1}-Z_{y-1}\right)+\rho^{-1} H^{-1} T_{y}\right] \\
& Z_{t+2}=Z+\frac{\Delta t}{\Delta x}\left[-H_{x+1} U_{x+1, t+1}+H_{x-1} U_{x-1, t+1}\right]+\frac{\Delta t}{\Delta y}\left[-H_{y+1} V_{y+1, t+1}+H_{y-1} V_{y-1, t+1}\right]
\end{aligned}
$$

Since values of $U$ are not available at $V$ points, and vice versa, the $V$ values required in the first of equations (3) are approximated by taking the average of the four $\mathrm{V}$ values lying nearest to the $U$ point (at interior

points) where the value is required. This value is represented by $\widetilde{V}$. The same procedure is used to get the $U$ value in the second of equations (3). At points near the boundary the corresponding averages use as many values at adjacent points as are available. In order to economize on computing, it is convenient to introduce the following nondimensionalized variables:

$$
\begin{array}{lll}
H^{*}=C^{-1} H & V^{*}=\frac{2 r \Delta t}{C} V & T_{y}^{*}=\frac{4 r \Delta t^{2}}{\rho c^{2}} T y \\
Z^{*}=\frac{2 r S}{C^{2}} Z & T_{x}^{*}=\frac{4 r \Delta t^{2}}{\rho e^{2}} T x & f^{*}=2 \Delta t f \\
U^{*}=\frac{2 r \Delta t}{C} U & &
\end{array}
$$

where

$$
c=\mathrm{s}^{2} / \mathrm{g} \Delta \mathrm{t}^{2}
$$

Here $\Delta \mathrm{x}$ and $\Delta \mathrm{y}$ have been taken equal, and are represented by $\mathrm{s}$. The difference equations (3) then become 


$$
\begin{aligned}
& U_{t+1}^{*}=U_{t-1}^{*}-H^{*-1} U_{t-1}^{*} \sqrt{U_{t-1}^{* 2}+\tilde{V}_{t-1}^{*-2}}+f^{*} \tilde{V}_{t-1}^{*}-Z_{x+1}^{*}+Z_{x-1}^{*}+H^{*-1} T_{x}^{*} \\
& V_{t+1}^{*}=V_{t-1}^{*}-H^{*-1} V_{t-1}^{*} \sqrt{\tilde{U}_{t-1}^{* 2}+V_{t-1}^{* 2}}-f^{*} \tilde{U}_{t-1}^{*}-Z_{y+1}^{*}+Z_{y-1}^{*}+H^{*-1} T_{y}^{*} . \\
& Z_{t+2}^{*}=Z^{*}-H_{x+1}^{*} U_{x+1, t+1}^{*}+H_{\alpha-1}^{*} U_{x-1, t+1}^{*}-H_{y+1}^{*} V_{y+1, t+1}^{*}+H_{y-1}^{*} V_{y-1, t+1}^{*}
\end{aligned}
$$

It may seem strange that the values of At and s occur in the nondimensionalizing scheme, but this allows further reduction in the number of arithmetic operations that must be performed at each step.

In order to avoid the simplest type of numerical instability, it is well known that the time step must be sufficiently small, according to

$$
\Delta \mathrm{t}<\mathrm{s} / 2 \sqrt{ } \mathrm{gH}
$$

In terms of the nondimensional parameters, this requires that

$$
\mathrm{H}^{*}<1 / 2
$$

at each point. The procedure is to choose $c$ such that the largest depth value in the grid satisfies (8). This value along with the $s$ of the grid determines the time step $\Delta \mathrm{t}$, and all the other nondimensionalizing factors of (4).

The region included in Figure 1 contains part of the steep slope at the edge of the shelf, including depths down to approximately $1000 \mathrm{~m}$. It is desirable to avoid these greater depths, in order that condition (7) or (8) allow a larger $\Delta t$, and to avoid also the steep slope, which effectively makes the discretized equations a poor approximation to the differential equations. This has been done artificially by arbitrarily substituting $200 \mathrm{~m}$ for all depths greater than this amount. The altered bathimetry is not greatly different from the real case, and it is believed that the errors thereby introduced are less important than those from other sources. 
In addition, the Malaka and Sunda Straits are arbitrarily closed off, as it would not be feasible to include them without greatly refining the grid size. The effect of this idealization is estimated a posteriori and seen to be small. WYRTKI (1961) considers the transports through these straits to be of minor importance to the general circulation.

\section{RESPONSE TO STEADY WINDS}

Two contrasting wind patterns were considered: (1) corresponding to the Northwest Monsoon in December; and (2) corresponding to the Southeast Monsoon in July (KonINKLIJK NEDERLANDS METEOROLOGISCHE INSTITUUT 1935, 1949). Although the winds in the Sunda Shelf region are particularly steady during these periods, it is nevertheless unlikely that any single synoptic wind pattern could be said to adequately characterize typical or average conditions. Also, the winds are variable enough so that vectorial time averages result in winds that seem far too weak.

It was found that 'reasonable' wind fields could be obtained in the following way. At each point the wind speed is taken to be a time average of the speed of the time-varying wind, and the wind direction is taken as that of the vectorially time-averaged wind. However, since the sea's response is likely to be sensitive to local divergences artificially introduced by this unusual averaging procedure, it was thought advisable to require that the wind field be non-divergent. This was done by introducing a stream function for the surface winds and determining it by making it fit the averaged winds in a least squares sense. Representing the stream function in a two-dimensional power series, it was found that the appropriate degree of spatial smoothness is achieved by including terms up through the third degree. Accordingly, there are ten parameters with which to represent the wind field. The resulting fields appear reasonable and typical (Figs. 2 and 3).

The wind stress is then determined by requiring that it be directed downwind with magnitude equal to

\section{$|\underline{I}|=, 0026 \rho_{a} W^{2}$}

where pa is air density and $\mathrm{W}$ is wind speed (SVERDRUP et al., 1946, Table 67). (The matter of variation of wind velocity with height above sea surface is not considered here).

The coefficient of friction $r$ is observed to have a value of approximately .002 to .004 in many cases. Here, the value .004 was used, but it may be worthwhile to try other values. 


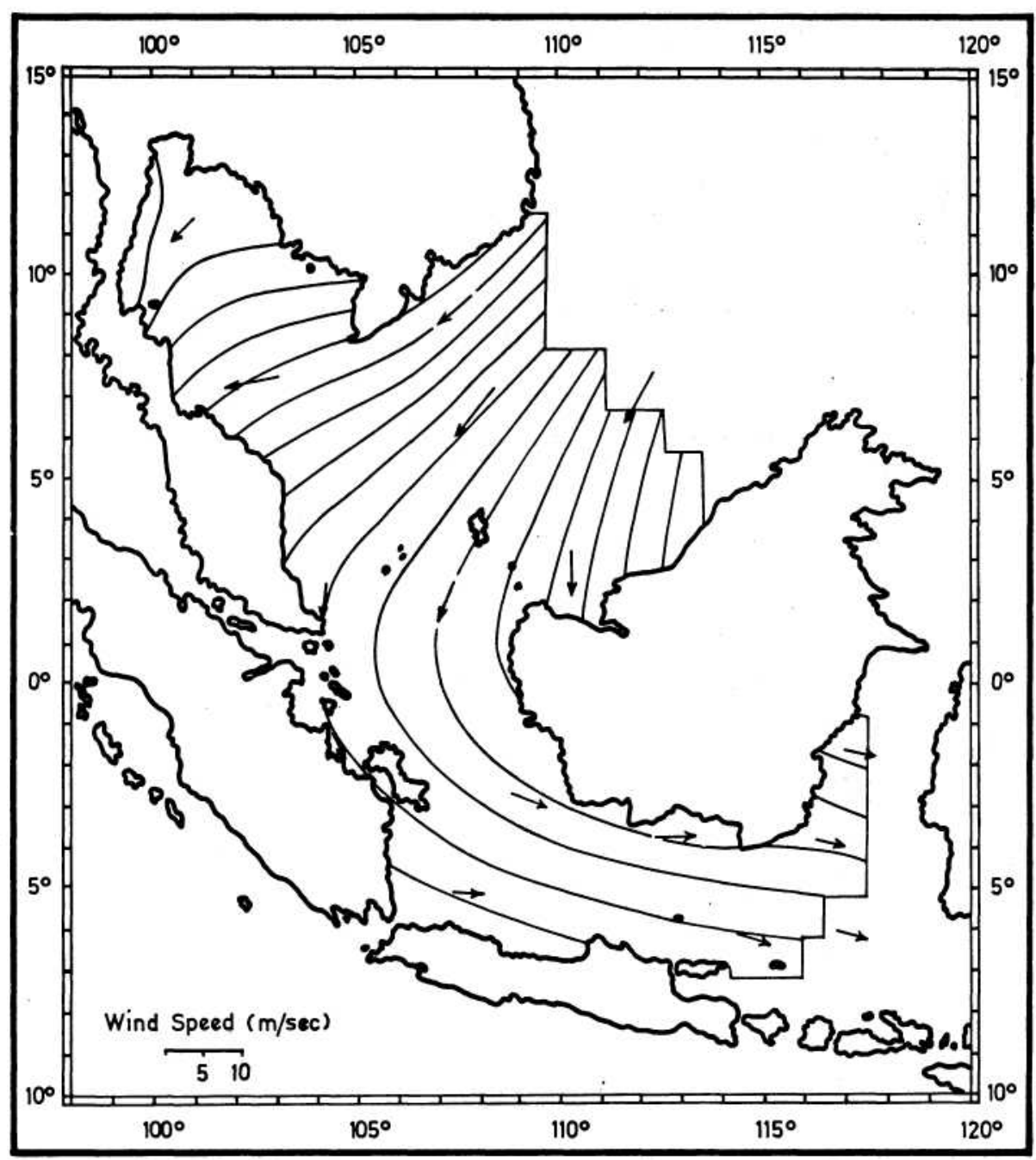

Figure 2.

Wind field streamlines for Northwest Monsoon. (The streamlines are a least-squares fit to the indicated arrows). 




Figure 3.

Wind field streamlines for Southeast Monsoon. (The streamlines are a least-squares fit to the indicated arrows). 
The simplest and most straightforward way to proceed is to initialize the sea-surface elevation and currents to zero and let the appropriate wind pattern start acting on the sea, beginning at time $t=0$. The amount of real time needed for the currents, etc., to come to equilibrium with the imposed wind field can be estimated by considering the periods of the free modes of oscillation.

The periods of the planetary modes have no upper bound, but they may not be important anyway. The very slow planetary seiches have short wavelengths and present a poor match to the smooth wind field and thus probably will not be appreciably generated. The gravest gravity mode can be estimated by considering a narrow canal, open at one end, closed at the other, with mean depth and length consistent with the dimensions of the Sunda Shelf. The resulting period is of the order of a hundred hours.

Several strategies were attempted in order to speed up convergence of the numerical scheme. Sometimes the wind stresses were arbitrarily augmented by a large factor for several hundred iterations in order to more quickly overcome the inertia of the water. This apparently did not introduce any serious difficulties, but the resulting current and surface configuration evidently differed enough from the equilibrium configuration that many more iterations at normal wind stresses were required. In the end, we were not convinced that anything worked any better than merely letting the iteration procedure run normally until inappreciable further change would occur in the spatial distributions and the total energy. The total energy $\mathrm{E}$ and net power input $\mathrm{P}$ were monitored continuously. These quantities are defined by

$$
\begin{aligned}
& E=1 / 2 \int\left[H\left(U^{2}+v^{2}\right)+g^{2}\right] d A \\
& P=\int\left[\dot{p}^{1} \underline{T} \cdot \underline{V}-\mathrm{r}\left(U^{2}+V^{2}\right)^{3 / 2}\right] d A
\end{aligned}
$$

where the integrals are over the surface area of the region considered. They obey the conservation law

$$
\mathrm{dE} / \mathrm{dt}=\mathrm{P}
$$

for the continuous case. The discretized versions of $\mathrm{E}$ and $\mathrm{P}$ were seen to approximately satisfy (11), but for some poorly understood reason, possibly connected to discretization error, P seemed biased downward. That is, whenever $\mathrm{E}$ appeared to remain constant from iteration to iteration, the value of $\mathrm{P}$ was usually slightly negative. 
The value of $\Delta t$ was roughly seven minutes in both cases, and the runs were terminated after about twenty five days of real time. The resulting current and surface configurations are shown in Figures $4,5,6$ and 7 .

In a similar application of this method for estimating the effects of winds over the Gulf of Bothnia, UUSITALO (1960) encountered numerical instabilities that necessitated the inclusion of artificial horizontal momentum transfer terms in the equations (LAX and RICHTMYER, 1956), but this procedure did not seem to be required here.

\section{RESULTS AND CONCLUSIONS}

The Sunda Shelf resembles a curved, open-ended canal with its axis through the Jawa Sea, the Karimata Strait and the South China Sea. During both monsoons the wind blows approximately along the axis of this canal (Figs. 2 and 3). Consequently, the resulting wind-driven circulation on the shelf should at least resemble a wind-driven flow through a canal. This extremely simple view provides a general picture which agrees well with the important features of the circulation in the model (Figs. 4 and 6).

During the Northwest Monsoon (referred to sometimes as the "Northeast Monsoon" or "Winter Monsoon" by Northern-Hemisphere observers) the strongest currents flow south westward along the coast of South Vietnam with a typical velocity on the order of $40-50 \mathrm{~cm} / \mathrm{sec}$. (Fig. 4). This relatively strong current splits on the Sunda Shelf with its western portion entering the Karimata Strait and the remainder returning northeastward along the coast to Kalimantan. As the southward flow squeezes through the Karimata Strait the current velocity increases from about $12 \mathrm{~cm} / \mathrm{sec}$ to $25 \mathrm{~cm} / \mathrm{sec}$. The current then travels eastward through the Jawa Sea in a near zonal flow with a typical speed of $15 \mathrm{~cm} / \mathrm{sec}$.

During the Northwest Monsoon the sea level slopes upward into the Gulf of Thailand with the elevation at Bangkok about $16 \mathrm{~cm}$ above the level at the open ocean boundary (Fig. 5). An intense, meridional sea surface slope develops in the Karimata Strait with a downstream drop of $10 \mathrm{~cm}$ in less than $200 \mathrm{~km}$.

During the Southeast Monsoon a near zonal current flowing through the Jawa Sea with a typical speed of $15 \mathrm{~cm} / \mathrm{s}$ squeezes into the Karimata Strait from the south (Fig. 6). In the strait the current accelerates to approximately $25 \mathrm{~cm} / \mathrm{sec}$. The current proceeds into the South China Sea as a strong boundary current along the coast of South Vietnam with speed as great as $60 \mathrm{~cm} / \mathrm{s}$. Here, an anticyclonic gyre develops with a relatively strong, southward flow along the northwest coast of Kalimantan. Within the western boundary current a small counterflow develops at the open ocean boundary at about $8^{\circ} \mathrm{N}$. This countercurrent may merely be a consequence of the open ocean boundary condition which meridionally limits the isochrones of equal sea level as they approach the open boundary (Fig. 7). Since it was not a major feature, 


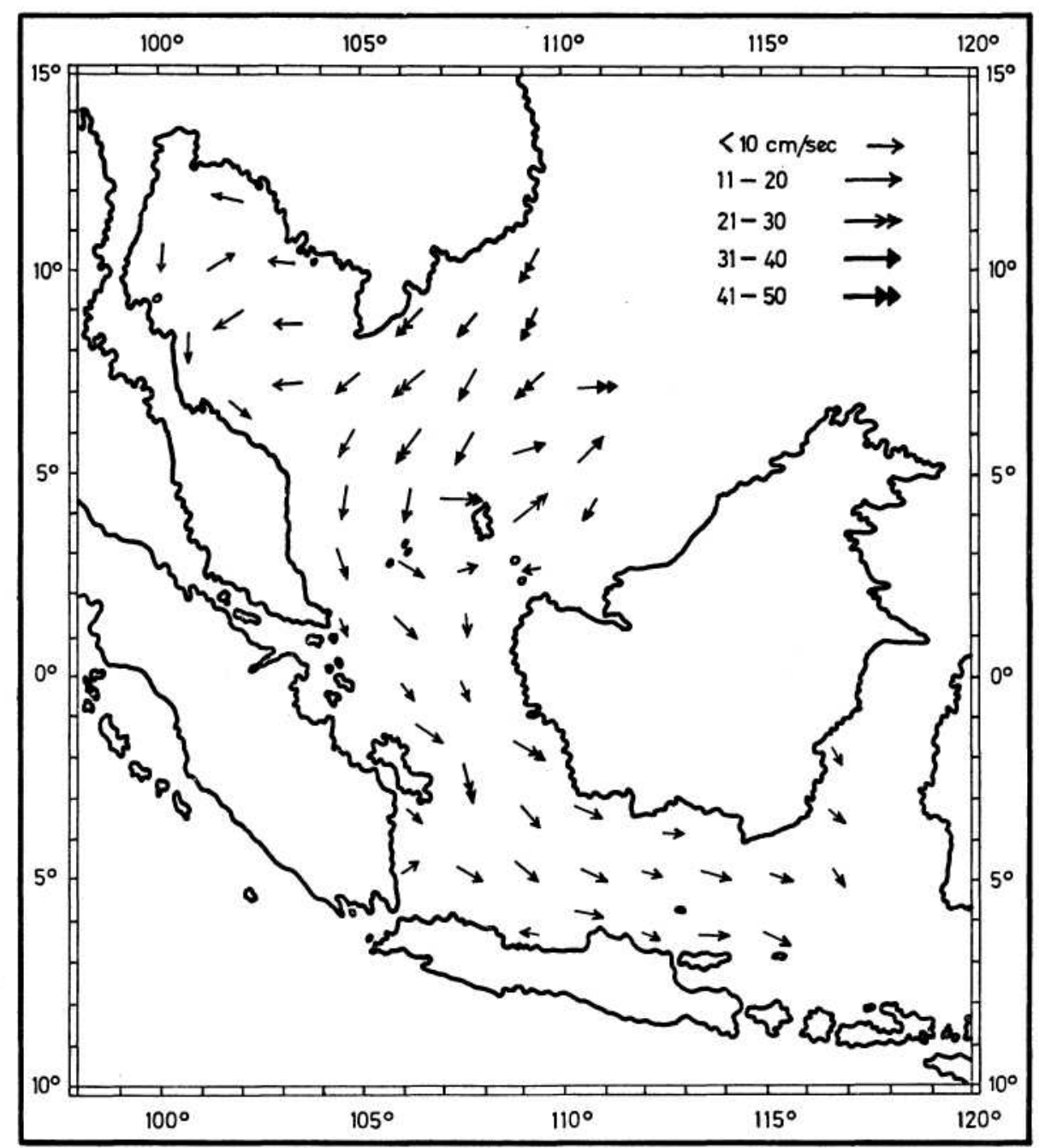

Figure 4.

Circulation developed during Northwest Monsoon. 


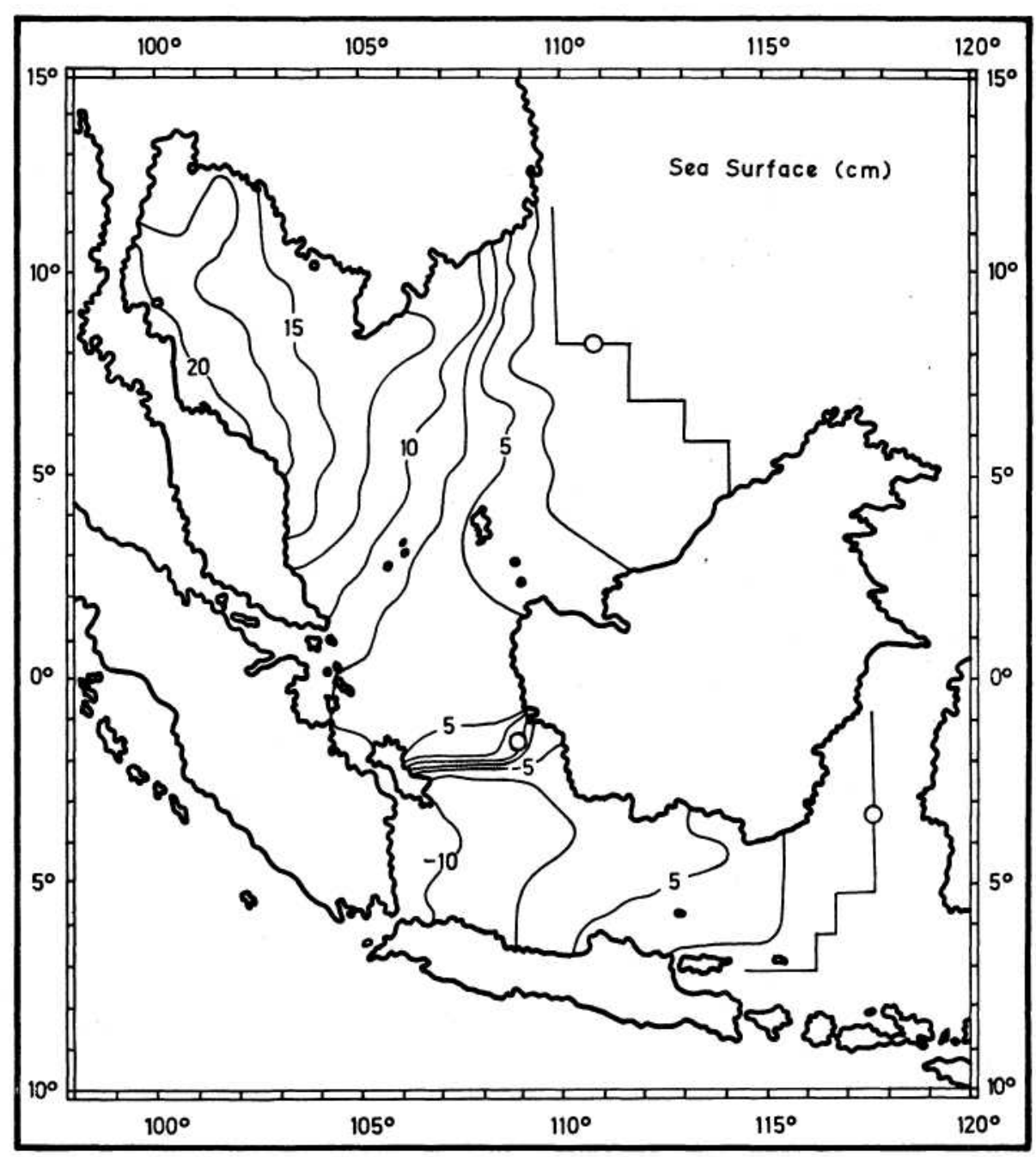

Figure 5.

Sea surface topography (in $\mathrm{cm}$ ) during Northwest Monsoon. 


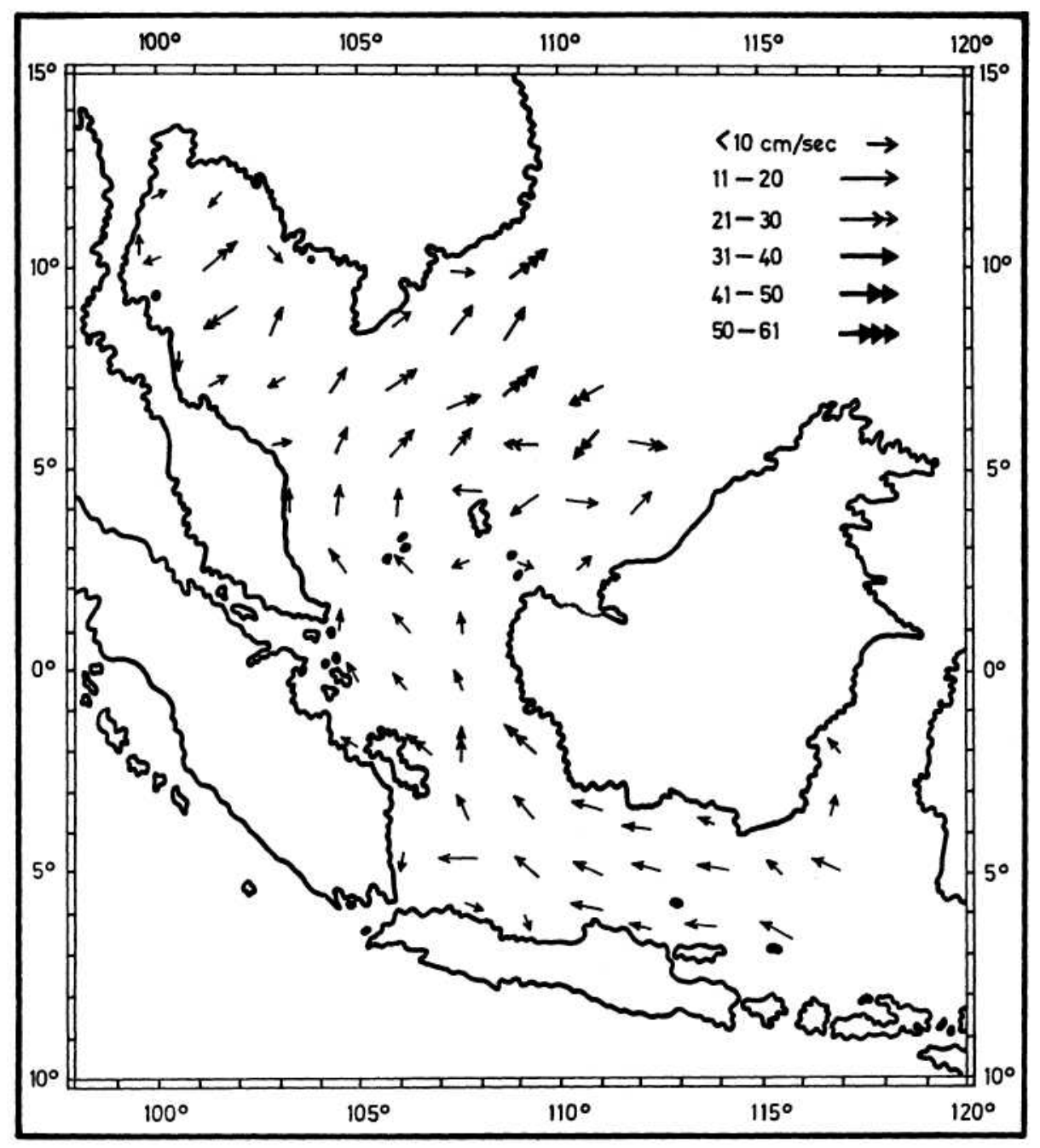

Figure 6.

Circulation developed during Southeast Monsoon. 


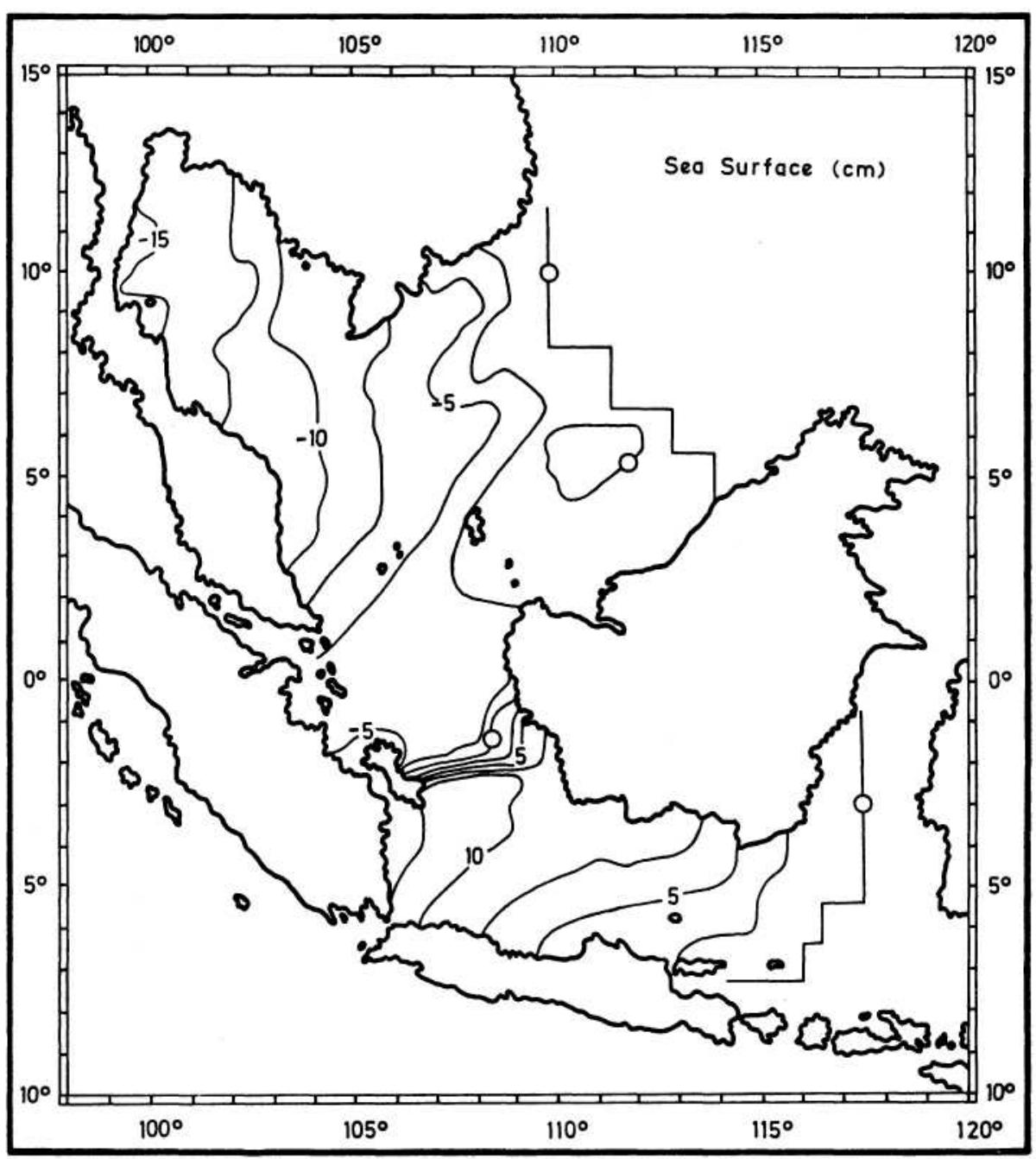

Figure 7.

Sea surface topography (in $\mathrm{cm}$ ) during Southeast Monsoon. 
this small counterflow did not warrant inclusion in the schematic representation of the current field. Nonetheless, it is easily detectable in the representation of the sea surface topography (Fig. 7).

During the Southeast Monsoon the sea level rises about $10 \mathrm{~cm}$ westward across the Jawa Sea. Again, a strong meridional slope develops in the Karimata Strait with a downstream drop of $10 \mathrm{~cm}$ in about $100 \mathrm{~km}$. In the Gulf of Thailand the sea level subsides while along the northwest coast of Kalimantan it remains fairly constant.

During both monsoons a system of eddies develops in the Gulf of Thailand. The eddies are believed to be the consequence of an atypical simulation of the winds in the gulf rather than a realistic circulation. In any case, these eddies have no apparent effect on the principal circulation of the Sunda Shelf.

The model is in good qualitative agreement with field data (WYRTKI 1961). The current velocities, however, appear to be slightly lower throughout the region considered. This discrepancy could be reduced by taking a smaller coefficient of bottom friction. Reducing the bottom friction would also bring the sea surface topography in the Karimata Strait into better agreement with WYRTKI's data. By hastening the flow through this shallow strait, the intense slope of the sea surface in the strait would be lessened. Also, these results indicate approximately the same intensity for the circulation in both monsoon seasons, whereas according to BERLAGE (1927) the currents during the northwest monsoon are about twice as strong.

North of the equator the contours of sea level are in generally good agreement with field data during both monsoons. The sea surface topography in the Jawa Sea, on the other hand, would appear to be in rather poor agreement (WYRTKI, 1961). However, in estimating the seasurface topography in the Jawa Sea, WYRTKI assumed the flow to be in approximate geostrophic balance. In the model, the wind streamlines slightly cross the zonal axis of the Jawa sea. This is sufficient to boost the wind stress term in the equation of meridional motion to the same order of magnitude as the geostrophic terms, and consequently the current and surface topography in the region are far from geostrophic balance. Also, the requirement of zero surface elevation along the open boundaries is inconsistent with the surface topographic charts of WYRTKI (1961), and may be inconsistent with reality. It is thus not surprising that there is some disagreement between our current patterns and those of WYRTKI. Better agreement might be achieved by specifying a more realistic surface profile along the open boundaries.

\section{ACKNOWLEDGEMENTS}

The authors are grateful to GARY MEYERS and R. KASTORO for their considerable help in setting up the grid and numerical procedure, and to ABDUL GANI ILAHUDE and KLAUS WYRTKI for their advice. The work was begun at LEMBAGA OSEANOLOGI NASIONAL, Jakarta, using the digital computer at PERTAMINA, and we thank SUJATNO BIROWO and E. SOENREDI of those offices for their valuable assistance. G.W. GROVES was supported 
while in Indonesia by a grant from the SMITHSONIAN INSTITUTION. The computations were completed at the Statistical and Computing Center of the University of Hawaii. This work was supported by the Oceanography Section, National Science Foundation, through Grant GA-17137.

\section{REFERENCES}

Berlage, H. P. Jr. 1927. Monsoon currents in the Java Sea and its entrances. Konin. Magnet. Met. Obs. Batavia. Verhandelingen 19: 1-28.

BRETTSCHNEIDER, G. 1967. Modelluntersuchungen der gezeiten der Nordsee unter anwendung des hydrodynamische-numerischen verfahrens. Mitt. Inst. Meeres. Hamburg 8: 1-49.

HANSEN, W. 1962. Hydrodynamical methods applied to oceanographic problems, Proceeding of the Symposium on mathematical-hydrodynamical methods of physical oceanography. Mitt. Inst. Meeresk. Hamburg 1:25-34.

KONINKLIJK NEDERLANDS METEOROLOGISCHE INSTITUUT 1935. No. 115. Oceanographische en meteorologische waarnemingen in de Chineesche Zeeen en in het westeljjk deel van den noord Stillen Oceaan. Government Printing Office, The Hague 1-2: $1-46$.

---------- 1949. No. 124. Zeegebieden rond Australie: Oceanographische en meteorologische gegevens. Staats drukkry - en uit geverybedrijf 'sGravenhage: $0-79$.

LAX, P. D. and R. D. RichtMeyer 1956. Survey of the stability of linear finite difference equations. Comm. Pure Appl. Math. 9(2): $267-293$.

Platzman, G. W. 1963. The dynamical prediction of wind tides on Lake Erie. Meteorological Monographs 4 (26): 1-44.

SVERDRUP, H. U., M. W. JOHNSON, and R. H. FLEMING 1942. The oceans, their physics, chemistry and general biology. Prentice-Hall, New York: 1 - 1087.

Uusitalo, S. 1960. The numerical calculation of wind effect on sea level elevations. Tellus 12 (4): 427-435.

WyrtKi, K. 1961. Physical oceanography of the Southeast Asian waters. Naga Rep. 2: $1-395$. 